American Journal of Agricultural and Biological Sciences 3 (3): 579-583, 2008

ISSN 1557-4989

(C) 2008 Science Publications

\title{
Evaluation of Micro and Macro Elements in Drought Stress Condition in Cultivars of Rapeseed (Brassica napus $\mathbf{L}$.)
}

\author{
${ }^{1}$ Mohammad Nasri, ${ }^{1}$ Mansoreh Khalatbari, ${ }^{2}$ Hossein Zahedi, \\ ${ }^{3}$ Farzad Paknejad, and ${ }^{1}$ Hamid Reza Tohidi Moghadam \\ ${ }^{1}$ Department of Agriculture, Islamic Azad University, Varamin Branch, Iran \\ ${ }^{2}$ Department of Agriculture, Islamic Azad University, Islamshahr Branch, Iran \\ ${ }^{3}$ Department of Agriculture, Islamic Azad University, Karaj Branch, Iran
}

\begin{abstract}
For study the effects of different levels of irrigating according to the 0, 25, 50 and $75 \%$ of field capacity to the amount of food less demand's elements in the number of 5 and Rapeseed (Brassica napus) line this experiment randomized complete block design had been executed in the field at 2002-2003 in the research field of agricultural university of Varamin, Azad University. The amount of the needed fertilizer had consumed according to the soil analysis of the test site. At the end of the research for determining the amount of each element in each caring, the leaf samples had transferred to the laboratory and the necessary examination had been performed. The result had been Variance analyzed with the help SAS software and the comparison of the data average had executed with the help of the multi amplitude test of Duncan. According to the results of Variance analysis, the difference of elements in the numbers and different lines of Rapeseed (Brassica napus) and the different levels of irrigating and the counter effect of these two factors had been meaningful in the level of $1 \%$ and among the numbers only the element of Sulphur had the statistical meaningful difference. The variety of Hyola-42 and Mohican had allocated the first and the last statistical class to itself orderly with the average of 1.94 and $1.03 \%$. The varieties were not meaningful in the case of the amount percentage of boron and $\mathrm{Zn}$ in the dry substance of leaf. Also in this study the different levels of irrigation has been meaningful effects on the amount of percentage of the elements 3 . With increasing of the intensity of drought stress from $75-0 \%$ the F.C amount of element have shown the decreasing amount and Sulphur had reached from 1.98-1.01\% and the Zinc had reached to the $15.2 \mathrm{mg}$ from $29.6 \%$ in the dry substance of the leaf. However the amount of the results had shown the reduction but they were meaningless in the case of statistic.
\end{abstract}

Key words: Rapeseed (Brassica napus), drought stress, the less consumption elements, variety

\section{INTRODUCTION}

In the conditions of drought stress and because of that the aperture are close for preventing from the transpiration it would have concluded the reduction in the $\mathrm{CO}_{2}$ 's absorption and would have the less producing the amount of dry substance and it would use the food elements with the less efficiency. This counter effect for the amount of humidity and nutriment elements are bilateral. In this case the role of the useless elements would show itself more than anytime because the limit between the sufficiency and lack of the nutritious elements are so close to each other and the small reduction in their absorption would lead to the lack of these elements and it would cause the reduction in the functioning. Sulphur would increase the resistance of plants in front of environmental stress ${ }^{[2,3]}$ But the amount of it in the plants in the drought stress would decrease very much as its lacking is obvious in the weather organs ${ }^{[10]}$. With the research that the researcher performed in the condition of humidity stress on Sulphur in Rapeseed (Brassica napus), they reached to this conclusion that the harsh reduction of sulphur in the Rapeseed (Brassica napus)'s organs would reduce the production of chlorophyll and photosynthesis reduction and the producing the dry substance would reduce and also the indicator of the harvesting would be reduce too ${ }^{[4]}$. Mendham et al ${ }^{[6]}$ are believe that with the reduction of absorbing Sulphur in the condition of dry stress besides the function reduction the efficiency amount o water consumption would also decreasing (WUE) in the Rapeseed (Brassica napus) and it would decrease the amount of leaf level indicator and so it would cause the increasing of roots in comparison with

Corresponding Author: Mohammad Nasri, Department of Agriculture, Islamic Azad University- Varamin Branch, Iran 
the aerial organs. Sulphur with synthesizing the protein in Rapeseed (Brassica napus) would cause the increasing of the plants tolerance toward the dry situation $^{[2,5]}$, but in the situation of harsh drought stress with the intense reduction in absorbing the sulphur the synthesis of protein would decrease and in first step with the hydrolyze of protein and changing it to the simple saccharin would try to stabilize the osmosis potential and its ingredient relatively water content ${ }^{[1]}$ but with the continues of the stress condition the Rapeseed (Brassica napus) would loose its tolerance and with decreasing in the turgor pressure the output of the water consumption would cause the harsh reducing of functioning ${ }^{[7,8]}$. As a result of drought stress in the Rapeseed (Brassica napus), for the stress inside the levels of the soil the $\mathrm{Zn}$ would be out of the plant reaches and would reduce harshly ${ }^{[5,12]}$. The reduction of the zinc elements as a result of dryness would cause the amount of Oxides and it would preventing from the transferring the Indol Ascetic Acid. The reduction of the amount of oxides would be as the result of increasing activity of the IAA Oxides ${ }^{[1]}$. In a research perform on the 5 variety of Rapeseed (Brassica napus) in the humid condition and in the $30 \%$ capacity of the field and $70 \%$. Vyas et al. ${ }^{[13]}$ had observed that the amount of Zinc had been reached to its minimum amount, means $18 \mathrm{mg} \mathrm{kg}^{-1}$ in the stress condition and this effect had been limited in the aerial parts and the functioning had reduced harshly. Rashid et al. ${ }^{[9]}$ in their research which have performed on the Rapeseed (Brassica napus) and its counter effect on the humidity stress in two humid levels in $35 \%$ of the field capacity and $80 \%$ of the field capacity, they understood that as a result of dryness the amount of boron had been decreasing and so the amount of water potential and WUE had been reduced and also in the humid stress condition with decreasing the absorption of the boron the amount of functioning in Rapeseed (Brassica napus) also reducing, although boron in the condition of irrigated land with the growth of root and the increasing the amount of stem to the root and also producing Carbohydrates and Synthesize would cause that they use efficacy from the moisture in the dry periods ${ }^{[1]}$, But the researches have shown that with increasing the drought stress harshness the amount of boron in the plant tissues and specially leaf would reducing and the amount of stomata guidance also would reduce ${ }^{[7]}$. In the most noted researches, the effects of boron elements have been studied on the process of the plant growth, in this research it had been effort that the effect of drought stress level on the amount of elements would study in the plants tissues.

\section{MATERIALS AND METHODS}

This research have been performed for determining the effect of different level of irrigating according to the process of changes in absorbing the low consumption food elements in leaf and their effects on the quality and quantity features in the Rapeseed (Brassica napus) genotypes of 5 variety and Rapeseed (Brassica napus) line of Hyola- 42, Syn-1, PF7045-01, Symbol, Mohican in the research field in agricultural Azad university in Varamin Unit in 2002-2003. The site of test performance is located in the geographical coordinates of 5139 western longitude and 3519 northern latitude and the height of 1000 meters from the sea level. These researches are performed as the breaking to peaces fields in the form of randomly blocks in 4 repetitions. Each genotype had cultivated in the length of 6 meter on the 6 mound and on each mound there were 3 lines of implants with the distance of $20 \mathrm{CM}$. the distance of mounds was $60 \mathrm{~cm}$ and the distance of shrubs on the rows was $5 \mathrm{~cm}$ and each repetition was include 20 fields in the $3.5 \times 6 \mathrm{~m}$ dimensions and acreage of $19 / 6 \mathrm{~m}^{2}$ that the two sides line was appointed as the border and the second line was appointed for taking notes and the third line was used for the function margin and the fourth lines was used for calculating the final function. Harvesting was performed at 20th October of 2002 and the needed fertilizer was used according to the soil test recommendation $300 \mathrm{Kg} \mathrm{ha}^{-1}$ urea and $100 \mathrm{Kg} \mathrm{ha}{ }^{-1}$ super Phosphate triple and $100 \mathrm{Kg} \mathrm{ha}^{-1}$ sulphate potassium that all the fertilizers except urea had been added in the time of furrowing and one of the third amount of urea fertilizer was consumed at the time of implanting and the remained of it was consumed two times, one at the beginning of stalking and the other in the time of flowering the blooming period. The date of beginning the applying the lack of water stress was performed in the growing phase of $4 / 5$ according to the coding of the Rapeseed (Brassica napus) growth period that in this phase 50\% of the total sprouts had been blossoming on the clusters in 4 levels. During the test and during nursing they chose 5 shrubs from the sampling level of each field randomly in four phases and features such as the amount of grains in the shrubs and seeds and the weight of its 1000 seeds calculated. There were two weeks to the harvesting in 26th of April 2002 that they separated a leaf sample and transfer it to the laboratory, because of the high volume of the work process some of the samples in the refrigerator located with the temperature of $5^{\circ}$ centigrade and gradually the leaf samples had been used for calculating the noted elements. In the first phase: the leafs have rinsed with the normal water and 
then they have rinsed with chloridric Acid 1\% in about less that $30 \mathrm{sec}$ and finally they have rinsed with the help of normal water and distilled water. The act of drying the leafs level was performed in the air and for determining the dry substance material of the samples they have located in the dryer with $70^{\circ}$ centigrade for about $48 \mathrm{~h}$. For determining the percentage of sulphur and zinc and boron, the dried samples were calculated by the atomic absorption equipment after become powder and with the help of the dry oxidation way or burning. The test of soil tissue has cleared after and before the research on the micro nutritious elements by the DTPA method ${ }^{[8]}$. The analysis of the low consumption elements variance was perform in the four level of irrigating and 5 variety and Rapeseed (Brassica napus) line with the help of SAS software and also the comparison of their average was performed with the help of multi dimension test of Duncan in the 5 and $1 \%$ levels. The related graphs were draw with the help of Excel software.

\section{RESULTS AND DISCUSSION}

Results obtain from the table of variance analysis shows that the studied varieties and lines have little difference in the case of Sulphur as the percentage of existing sulphur in the dry substance of leaf was located in Hyola-42 and two lines of Symbol and Mohican were located with the average of 1.03 and $1.18 \%$ sulphur in the second statistical class. The drought stress caused that the percentage of Sulphur in the leaf surface become located in the different groups of statistic. That means the effects of dry surfaces have been meaningful effects on the percentage of Sulphur. The maximum amount of sulphur in each treatment was 75 and $50 \%$ of FC and the minimum amount of it in two treatments was 25 and $0 \%$ of the field capacity. Although the behavior of $\mathrm{b} 4$ with the mean 1.98 and the behavior of b1 with the mean $1.01 \%$ of sulphur in the dry substance had located orderly at the top and the down of the sulphur average comparison table in the level of drought stress (Table 1).
The effects of the simple variety have no meaningful effect on the zinc element, although the varieties and lines had orderly 29.7, 28.6, 29.3, 25.6 and $28.2 \mathrm{mg} \mathrm{kg}^{-1}$ zinc on the dry substance, but the drought stress caused the deduction amount of zinc in the plant. According to the meaningfully of the effect of drought stress surface on the amount of zinc in the leaf dry substances, the fourteen fold levels of dryness level was located in the 3 separate statistic groups. The maximum amount of zinc on the leafs was related to the two treatments of b4 and b3 with the average 29.6 and $28.6 \mathrm{mg} \mathrm{kg}^{-1}$ of dry substance and the minimum amount also was related to the b1 treatment with the average of $15.2 \mathrm{mg} \mathrm{kg}^{-1}$ of the leafs dry substances that they located in the third place of statistic. In this study the only elements which have no meaningful difference among the varieties and dryness surfaces was $B$. Although the table of comparing the related average shows that with increasing the drought stress to the plant the amount of existed boron in leafs also reducing so the highest amount of boron among the varieties was related to the variety Hyola- 42 with the average of $21.2 \mathrm{mg} \mathrm{kg}^{-1}$ and the minimum amount was in the variety Mohican with the average of $18.25 \mathrm{mg} \mathrm{kg}^{-1}$. Also among the dryness surfaces, the maximum amount was related to the b4 treatment with the average of $20.18 \mathrm{mg} \mathrm{kg}^{-1}$ and the minimum amount also was related to the b1 treatment with the average of $19.45 \mathrm{mg} \mathrm{kg}^{-1}$ on the dry substance of leafs in Rapeseed (Brassica napus) plant. But in the case of statistic these differences was no meaningful. According to the table of average comparison, the counter effects of varieties in the drought stress surface are become meaningful for all the elements except the boron element. Besides the more drought stress was imposed on the plant but the food elements amounts have shown the more deduction. The maximum amount of elements have been observed in the counter reactions in the following treatments: sulphur, a2b3(Pf0745.01 line and 50\% F.C.), zinc, a1b4(Hyola-42 and 75\% F.C.) and boron, a2b3(Syn-1 line and $50 \%$ F.C.) and the minimum amount of elements also in the counter reactions includes: sulphur,

Table 1: Analysis of variance

\begin{tabular}{|c|c|c|c|c|c|c|c|c|c|}
\hline \multirow[b]{2}{*}{ SOV } & \multirow[b]{2}{*}{ (df) } & \multicolumn{8}{|l|}{ MS } \\
\hline & & $\begin{array}{l}\text { No. of pods } \\
\text { per plant }\end{array}$ & $\begin{array}{l}\text { No. of seeds } \\
\text { per plant }\end{array}$ & $\begin{array}{l}1000 \text { Seeds } \\
\text { weight. }(\mathrm{g})\end{array}$ & $\begin{array}{l}\text { Seed yield } \\
\left(\mathrm{Kg} \mathrm{ha}^{-1}\right)\end{array}$ & $\begin{array}{l}\text { Oil } \\
\text { percent }\end{array}$ & $\begin{array}{l}\mathrm{S} \% \text { in dry } \\
\text { matter }\end{array}$ & $\begin{array}{l}\mathrm{Zn} \\
\mathrm{ppm}\end{array}$ & $\begin{array}{l}\text { B } \\
\text { ppm }\end{array}$ \\
\hline Block (R) & 3 & 120.35 & $0.089^{\text {ns }}$ & $0.0029^{\mathrm{ns}}$ & $1.29^{\mathrm{ns}}$ & $1.88^{\mathrm{ns}}$ & $5.84^{\mathrm{ns}}$ & $120.35^{* *}$ & $0.89^{\text {ns }}$ \\
\hline Variety (A) & 4 & $25463.20^{* *}$ & $62.18 * *$ & $4.95^{* *}$ & $825892.45^{* *}$ & $5.26^{\mathrm{ns}}$ & $29.87^{* *}$ & $63.20^{\mathrm{ns}}$ & $6.18^{\text {ns }}$ \\
\hline Error (a)E & 12 & 186.56 & 0.78 & 0.0022 & 53564.8 & 3.99 & 3.097 & 186.25 & 0.78 \\
\hline Drought stress (B) & 3 & $18986.42^{* *}$ & $1018.31^{* *}$ & $11.02^{* * *}$ & $98425601^{* *}$ & $24.01^{* *}$ & $34.86^{* *}$ & $18986.42 * *$ & $18.31^{\mathrm{ns}}$ \\
\hline Variety*drought stress $(\mathrm{AB})$ & 12 & $21493.31^{* *}$ & $78.45^{* *}$ & $6.25^{* *}$ & $872222.45^{* *}$ & $2.98^{\mathrm{ns}}$ & $30.25^{* *}$ & $21493.31^{* *}$ & $78.45^{* *}$ \\
\hline Error (b)E & 45 & 104.35 & 1.133 & 0.0218 & 53581.4 & 1.812 & 2.84 & 104.35 & 0.75 \\
\hline
\end{tabular}


Am. J. Agri. \& Biol. Sci., 3 (3): 579-583, 2008

Table 2: Means comparison of yield and yield components of five cultivars rapeseed

\begin{tabular}{|c|c|c|c|c|c|c|c|c|c|}
\hline $\begin{array}{l}\text { Treatment } \\
\text { cultivar }\end{array}$ & $\begin{array}{l}\mathrm{S} \% \text { in dry } \\
\text { matter }\end{array}$ & $\begin{array}{l}\mathrm{Zn} \\
\left(\mathrm{mg} \mathrm{kg}^{-1}\right)\end{array}$ & $\begin{array}{l}\mathrm{B} \\
\left(\mathrm{mg} \mathrm{kg}^{-1}\right)\end{array}$ & $\begin{array}{l}\text { Seed yield } \\
\left(\mathrm{Kg} \mathrm{ha}^{-1}\right)\end{array}$ & Oil (\%) & $\begin{array}{l}\text { No. of pods } \\
\text { per plant }\end{array}$ & $\begin{array}{l}\text { No. of seeds } \\
\text { per plant }\end{array}$ & $\begin{array}{l}1000 \text { Seeds } \\
\text { weight (g) }\end{array}$ & $\begin{array}{l}\text { Oil yield } \\
\left(\mathrm{Kg} \mathrm{ha}^{-1}\right)\end{array}$ \\
\hline$\left(a_{1}\right)$ Hyola-42 & $1.94^{\mathrm{a}}$ & $29.7^{\mathrm{a}}$ & $21.2^{\mathrm{a}}$ & $3377.5^{\mathrm{a}}$ & $41.5^{\mathrm{a}}$ & $175.4^{\mathrm{a}}$ & $15.7^{\mathrm{a}}$ & $3.9^{\mathrm{a}}$ & $1401.7^{\mathrm{a}}$ \\
\hline$\left(a_{2}\right)$ Syn-1 & $1.94^{\mathrm{a}}$ & $28.6^{\mathrm{a}}$ & $20.8^{\mathrm{a}}$ & $3111^{\mathrm{a}}$ & $41.5^{\mathrm{a}}$ & $161.4^{\mathrm{a}}$ & $16.2^{\mathrm{a}}$ & $3.8^{\mathrm{b}}$ & $1291^{\mathrm{ab}}$ \\
\hline (a) PF7045-01 & $1.82^{\mathrm{a}}$ & $29.3^{\mathrm{a}}$ & $17.25^{\mathrm{a}}$ & $3609^{\mathrm{b}}$ & $41.6^{\mathrm{a}}$ & $131.5^{\mathrm{b}}$ & $17.8^{\mathrm{a}}$ & $3.8^{\mathrm{b}}$ & $1057^{\mathrm{c}}$ \\
\hline$\left(a_{4}\right)$ Mohican & $1.03^{\mathrm{b}}$ & $28.6^{\mathrm{a}}$ & $19.41^{\mathrm{a}}$ & $2062.3^{\mathrm{c}}$ & $41.7^{\mathrm{a}}$ & $99.2^{\mathrm{c}}$ & $12.8^{\mathrm{b}}$ & $2.7^{\mathrm{c}}$ & $817.7^{\mathrm{d}}$ \\
\hline (a) Symbol & $1.18^{\mathrm{b}}$ & $28.2^{\mathrm{a}}$ & $18.25^{\mathrm{a}}$ & $1947^{\mathrm{c}}$ & $42^{\mathrm{a}}$ & $14.9^{\mathrm{b}}$ & $14.3^{\mathrm{b}}$ & $2.9^{\mathrm{c}}$ & $860^{\mathrm{d}}$ \\
\hline FC $0 \%$ & $1.01^{\mathrm{b}}$ & $15.2^{\mathrm{c}}$ & $19.45^{\mathrm{a}}$ & $1788.2^{\mathrm{c}}$ & $40.2^{\mathrm{b}}$ & $82.8^{\mathrm{d}}$ & $13.9^{c}$ & $2.8^{\mathrm{d}}$ & $753^{\mathrm{c}}$ \\
\hline FC $25 \%$ & $1.22^{\mathrm{b}}$ & $21.3^{\mathrm{b}}$ & $19.88^{\mathrm{a}}$ & $2234^{\mathrm{b}}$ & $40.2^{\mathrm{b}}$ & $102.2^{\mathrm{c}}$ & $14.8^{\mathrm{bc}}$ & $3.3^{\mathrm{c}}$ & $923^{\mathrm{b}}$ \\
\hline FC 50\% & $1.8^{\mathrm{a}}$ & $28.6^{\mathrm{a}}$ & $19.89^{\mathrm{a}}$ & $3122.8^{\mathrm{a}}$ & $40.3^{\mathrm{b}}$ & $151.8^{\mathrm{b}}$ & $16.2^{\mathrm{b}}$ & $3.9^{\mathrm{b}}$ & $1355^{\mathrm{a}}$ \\
\hline FC 75\% & $1.98^{\mathrm{a}}$ & $29.6^{\mathrm{a}}$ & $20.18^{\mathrm{a}}$ & $3340.4^{a}$ & $43.1^{\mathrm{a}}$ & $182.4^{\mathrm{a}}$ & $18.7^{\mathrm{a}}$ & $4.2^{\mathrm{a}}$ & $1343^{\mathrm{a}}$ \\
\hline
\end{tabular}

a4b1(Symbol variety and 0\% F.C.), zinc, a5b2(Mohican variety and $0 \%$ F.C.) and boron, a5b3(Mohican and $50 \%$ F.C.) that they located at the lowest part of the average comparison table. As we noted above, the simple effects of varieties was only have the meaningful difference in the sulphur element. According to the role of sulphur in the plant, the dryness varieties would preserve the amount of this element in the maximum limit and in addition to the pervious noted reasons such as RWC, water potential, WUE and the ratio of the root to the aerial parts; this element also can increase the plant tolerance by using different methods ${ }^{[4]}$. Sulphur which is the forth needed elements for the Rapeseed (Brassica napus) and which is play an important role in the protein structures especially chlorophyll and at last which is playing an important role in the Rapeseed (Brassica napus) photosynthesis, although the amount of absorbing sulphur had been reduced by the increasing of stress harshness, but sulphur with hydrolyzing the protein and changing it to the simple saccharine was so effective in increasing of variety tolerance of Hyola-42 and two lines of Syn-1 and Pf7045.01 towards the dryness ${ }^{[5]}$. Being accessible of the boron element for the plant also would depend on the amount of soil humidity and the low humidity is caused that the boron element would not get accessible to the plant. He believes that the density of some of the elements in the condition of high drought stress would increase and some of them would decrease, so the dryness has bilateral effects on the plants. Like the lace of water preparation and lack of absorbing the nutritious elements. In this study also one of the reasons in deducting the boron elements in the high levels of drought stress was these factors. Also the effects of drought stress on the amount of zinc was meaningful as if the amount of this elements was reached to the $15.2 \mathrm{mg} \mathrm{kg}^{-1}$ from $29.6 \mathrm{mg} \mathrm{kg}^{-1}$ in the irrigating condition according to the $75 \%$ of the field capacity in its highest level of drought stress (Table 2). The reason would be as follows: the low humid soils would stabilize the zinc element. The plants that are under the drought stress would absorb the nutritious elements so slowly ${ }^{[13]}$. Accessible of the Rapeseed
(Brassica napus) to the Potassium, phosphor, boron, copper and zinc would be more important although the absorption of the zinc element in the plant would perform through the active absorption and the Rapeseed (Brassica napus) in comparison with the wheat would need two times zinc ${ }^{[8]}$. Drought stress would decrease the amount of absorbing these elements and so the growth of aerial parts would become limited and the amount of photosynthesize would decrease and finally the function would show the impressive diminishment $^{[3]}$.

\section{REFERENCES}

1. Barszcask, Z., T. Barszcsak, T. Gorczinsk and A. Kot, 1991. Sensibility of tropics of winter rapeseed to higher concentration of $\mathrm{Zn}$ : MC greyor. In: Proceeding of the 8th International Rapeseed Congress. Canada Organizing Committee, Saskatoon, pp: 1193-1196. URL: wwwmat21.slu.se/eng/publications/index.

2. Evans, H.J. and G.J. sorger, 1966. Role of mineral elements with emphasis on the univalent cations. Annu. Rev. Plant Physiol., 17: 47-70. URL: http://arjournals.annualreviews.org/doi/pdf/10.1146 /annurev.pp.17.060166.000403.

3. Foot, R.L., 2001. Comparative Responses of Field Grown Crops to Phosphate Concentrations in Soil Solutions. In: Stress Physiology in Crop Plants, Mussell, H. and R.C. Stapley (Eds.). Wiley, New York, pp: 81-106. URL: www.publish.csiro. au/?act=view_file\&file_id=AR9760479.

4. Grant, G.A. and L.D. Baily, 1993. Fertility management in canola production. Can. J. Plant Sci., 73: 651-870. URL: www.gov.mb.ca/ agriculture/crops/oilseeds/bga01s01.

5. Jakson, F. and Z. Jasinka, 1996. The influence of sowing dates and sowing rates on the development and Yield of winter rape varieties. In: Proceeding of 7the International. Rapeseed Conry Poznan, Poland, pp: 886-892. URL: http://journals. cambridge.org/production/action/cjoGetFulltext?fu lltextid=646056. 
6. Mendham, N.J., P.A. Ship way and R.K. Scott, 1998. The Effect of delayed sowing and weather on growth development and yield of winter oilseed rape (Brassica napus). J. Agric. Sci., 98: 389-416. URL: http://linkinghub.elsevier.com/retrieve/pii/ S1161030102001363.

7. Mogensen, V.O., C.R. Jonsen and H.H. Poulsen, 1995. Reflectance index for early determination of water stress. International Symposium of Irrigation in Australian. URL: www.actahort.org/ books/449/449_55.htm.

8. Nuttall, W.F., C.C. Boswell, A.G. Sinc, SOT.Ap. Moulin, L.J. Townley Smith and G.L. Gallway, 1993. The effect of time application and Placement of sulphur fertilizer source on yield of wheat Canola and barley common. Soil Sci. Plant Anal., 24: 2143-2202. URL: www.springerlink. com/index/r27n51951427686k.

9. Rashid, A., E. Rafique and N. Bughio, 1994. Diagnosis zinc boron deficiency in rapeseed and mustard by seed analysis and soil testing. Commun. Soil Sci. Plant Anal., 25: 3405-3412. URL: www.springerlink.com/index/
10. Sharp, R.E. and J.W. Davies, 1984. Root growth and water uptake by maize plants in drying soil. Exp. Bot., 36: 1441-1456. URL: http://jxb. oxfordjournals.org/cgi/content/abstract/36/9/1441.

11. Shen, Z.G., K. Shan and X.S. Zhang, 1998. Intractions among boron nitrogen and growth in oilseed rape. J. Nany. Agric. Univ., 16: 21-26. URL: http://www.gwf.org.bd/IJSCP/ V2I2March2007.

12. Wright, P.R., J.M. Jessop, R.S. and A. Cass, 2000. Comparative adaptation of canola (B. napus) and Indian mustard (B. juncea) to soil water deficits yield and yield components. Field Crops Res., 42: 11-13. Doi: 0378-4290(95)00013-G.

13. Vyas, S.P., B.K. Garg, S. Kathju and A.N. Lahiri, 1995. Influence of nitrogen on Indian mustard grown under different levels of stored soil moisture. J. Arid Environ., 29: 173-184. URL: http://linkinghub.elsevier.com/retrieve/pii/S014019 6305800886. 